\title{
Concept of Form and Space in Buginese Aristocratic Traditional House in Bone South Sulawesi
}

\author{
A.M. Akbar, Ananto Yudono, Ria Wikantari and Mohammad Mochsen Sir \\ Department of Architecture, Faculty of Engineering, Hasanuddin University, \\ South Sulawesi, Makassar, Indonesia
}

\begin{abstract}
Existence of Buginese aristocrat traditional house in Bone is greatly influenced by social stratification applied by the community; this causes differences on manifestation of form and space. It should guess that Bone aristocrat houses pay attention to some similarity with Buginese houses but since, Bone aristocrat historically has its own background (different to common people), this leads to differences on essential physical manifestation of its houses which is conducted to manifest description of dominant treasure ad cultural heritage eastern Indonesia and there are yet any in-depth researches on these issues. This research aims to find out the concept of form and space in Buginese aristocrat traditional houses and other factors which influence. Focus of the research is Buginese aristocrat houses in Bone Regency. Type of research is qualitative with rationalistic paradigm. Results of the research are: concept of the form has the principle of "Social millieu" namely the house serves as expression of aristocrat role static in presenting its stratification as a form of attaching unity in order to show its social status, concept of space has the principle of "Cultural symbolization" namely space serves as a symbol of micro-cosmos manifestation that is trusted by their ancestors, then it is known, related as well as given symbolic meaning, then identified based on its community culture which describe specific characteristics of the space, the factors influences on its are social environment and acculturation process of modern values.
\end{abstract}

Key words: Form, space, traditional house, Bone Buginese aristocrat, social status, modern values

\section{INTRODUCTION}

Traditional Buginese architecture in Indonesia is definitely related to the history of Buginese Kingdom in the past and Bone as the center of the largest Buginese kingdom in South Sulawesi at that time, it was very strategic as the gateway to the East coast of Sulawesi island and had a very long coastline stretching from North to South in Bone bay (Akbar et al., 2016). The cultural heritage inherited from the Bone Kingdom in South Sulawesi is the Saoraja Petta Ponggawa'E palace which was built during the 30th King Bone of La Pawawoi Karaeng Sigeri around 1890 and an ancient Buginese record called as lontaraq la galigo (Pelras, 2006).
In lontaraq la galigo, the traditional house of the Buginese Bone tribe is built based on customs based on social strata of house owner with a form of stilt and made of wood (Rahman, 2012). There are three types of traditional Buginese houses in Bone, namely: Saoraja consisting of two words namely Sao and Raja which means the King's House or palace of the Bone King, Salassa is a house occupied by royal officials and royal descendants, Bola is a house occupied by ordinary people (Fig. 1a-c).

In the preliminary survey, the researchers find that it still can be found out traditional houses of Buginese aristocrats and there are scattered in various parts of Bone
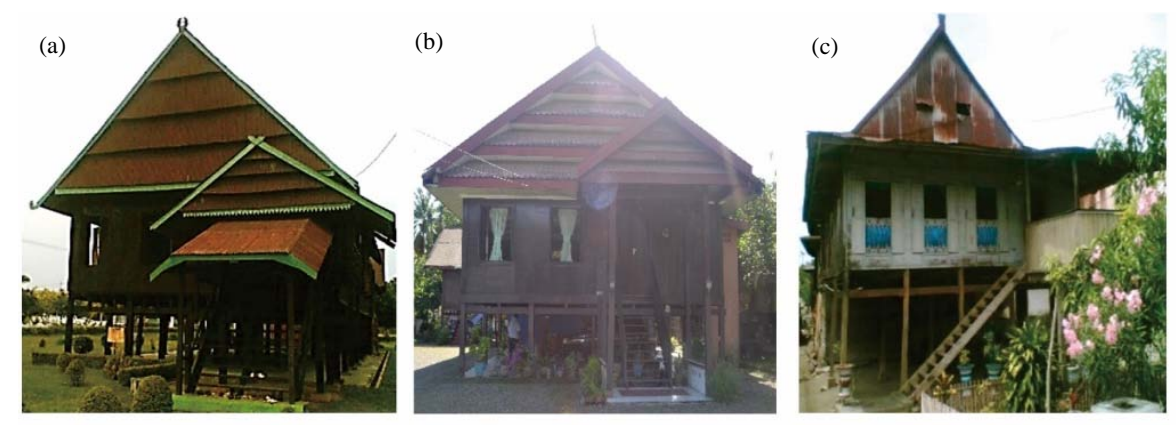

Fig. 1 (a-c): Buginese Bone traditional houses (a) Saoraja (b) Salassa and (c) Bola 
Regencies which are still inhabited by aristocrat descendants but some of which are in a very poor or damaged condition left by their owners. Existence of traditional house of Buginese aristocrats in Bone has historical value and if it is not documented as soon as possible, then there are certainly extinction by the time. Loss of historical heritage evidence will make it difficult to disclose its cultural values (Yudono, 2008).

The study aims to find out the concept of form and space which is adopted in traditional house of Buginese aristocrats and the factors giving influences.

\section{MATERIALS AND METHODS}

This type of research is qualitative with a rationalistic paradigm which is adopted from a theoretical framework and is built from meanings of previous research results, so that, the sources are able to uncover the truths as the basis of analysis on the concepts of form and space. The samples are determined purposively with the Buginese aristocrat houses in Bone as the populations. Sample criteria maximize the diversity of form and specifically, describe the concept of space, while simultaneously, these represent a larger group of houses.

Theory of form in Buginese traditional house: The philosophy of the traditional Buginese house is from an understanding on the universe universally, it is stated that there will be all aspect perfection of human life if they are rectangular (sulapa eppa). This philosophy originates from the myth of the human origin events which are believed to consist of four natural elements, namely: Earth, water, fire and wind. All elements relating to construction of houses must be based on cosmological expressions in the form of symbolic-philosophical meaning which are known from generation to generation.

Theory of space in Buginese traditional house: The philosophy of traditional Buginese house space is influenced by the understanding that the universe is divided into three parts: upper natural space is occupied by a single God (Dewata Seuwae), middle natural space is this Earth which is inhabited by the king as the representative of the god which regulates human social relations with the environment, the lower natural space is the lowest place (Uriliyu) which is inhabited by evil creatures (Koolhof, 1999).

Factors influencing on manifestation of traditional house architecture: According to Rapoport (1969) socio-cultural factors are determinants of the manifestation of traditional home architecture because it has a system of cultural values which will guide humans in perceiving and understanding the natural surroundings. The difference in the house form depends on the community response to the physical, social, cultural and economic environment, while it will be more visible to find physical and cultural variables, if the community perception and values have been understood (Oliver, 2003).

\section{RESULTS AND DISCUSSION}

Form of Buginese aristocrat traditional houses in Bone: The traditional house form of Buginese nobles in Bone is made of wood obtained from forests in Bone Regency such as teak, ironwood and merbau, since, it is considered a strong material. The use of wood is also considered to have good symbolic meaning. The basic Form of the house is divided into three parts, namely: the bottom part, consisting of wooden poles supported by several beam joint construction called as pattolo, it functions to connect one pole to another pole towards the length and width house direction. The construction system vertically is called as mappasituppu, namely an arrangement of wooden beam structures without nails. Furthermore, there is also arateng which is flat beams with length of less than the length of the house, serving as a base to lay the house poles and as a base for laying pallangga as the foundation of the body floor of the house, the form of the house body consisting of two main components, namely floor and walls. The house floor is not flat because of the hallway (tamping) functioning as a circulation. Tamping also serves as a symbol of the nobility degree and as a boundary for guest movement in the house. The flooring is made of thick wooden planks supported by cubs (arateng) with a distance of 20-50 cm which rests on the pattolo. Wall as a material covering the house body form is using a board with a pinch system, the form of the house top or roof is the main indicator of the basic form of the Buginese aristocrat house in Bone which tends to be hierarchical by looking at the social structure of house residents in their community. The construction of the saddle-shaped triangular roof shows a solid and stable unity to show power. The components consist of a beam (suddu) which is located in the middle between the rod beam (bara) which functions as a mounting beam for the ridge (allekena). The roof height is adjusted to the nobility degree. The horse legs (pasolla) function as a place to hold the gording beams (pakelleng) and as a barrier to the roof. Rodent beam (Pattolo riase) is a beam that connects the top end of the pole from each row to the left and right width of the house, the length is less than the width of the house. Bara is a beam that connects the top of the house pole to the length direction. Its function is as a place to put the timpalaja and a place to lay the bara rakkeang. Timpalaja is a symbol of the nobility degree of the homeowner which is seen directly in the house shape, the construction is in the form of a triangle and made in tiers, the main frame rests on the bara beam. 


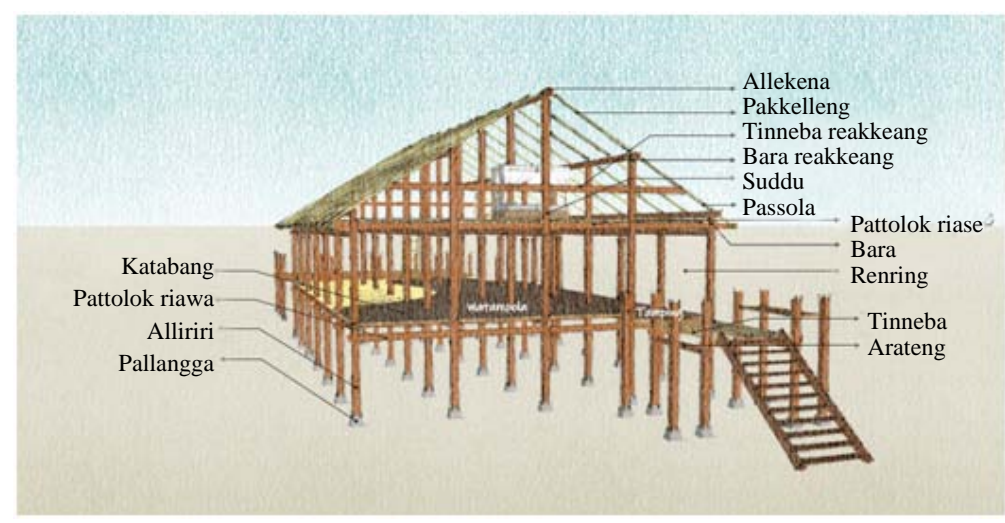

Fig. 2: Basic form of Buginese aristocrat traditional houses in Bone

Les plank (ciring) is in the form of a board mounted on the lower part of the roof, functions as a windbreak that holds the passola beam with a pen connection system, the end of the beam is carved with decoration. The roofing material now uses zinc, before it used dried nipa leaves (Fig. 2).

Composition of the form has a firm unity with a triangle form on the gable and a rectangular form on the house body as covered by carved walls and supported by large house poles which greater scale of the building's height than the building width is an expression of greatness in the size of Buginese traditional houses while the form of the facade elements is most prominent by the roof arrangement (timpa laja). This timpa laja is not only as a structure for the front and rear roof coverings or as a vent in the gable roof, it is as well as the symmetry axis of the total point symbolizing the status of aristocracy and charisma of home owner.

Type and characteristics of space: In the view of the Buginese aristocrats in Bone, the house serve as a form of microcosm which is analogous vertically consisting of three types of space, namely: Rakkeang located in the upper room, here, it is attached to ceiling structure and foundation of its roof construction. This room is sacred which functions as a meditation room for the king to maintain its relationship with his god and a sacred heirloom or sacred attribute of royal property. Besides this room, there is also a place to play for the king's daughter who is also sacred. In contrast to common people house, this space functions as a warehouse for storing rice, Ale Bola is located in the middle of the room, as a place for daily residents of the house, this room is also horizontally divided into several plots with different functions, Awa Bola is located at the bottom part of the house, generally, the left side is empty because it is considered a place where there are any living bad creatures (Fig. 3).

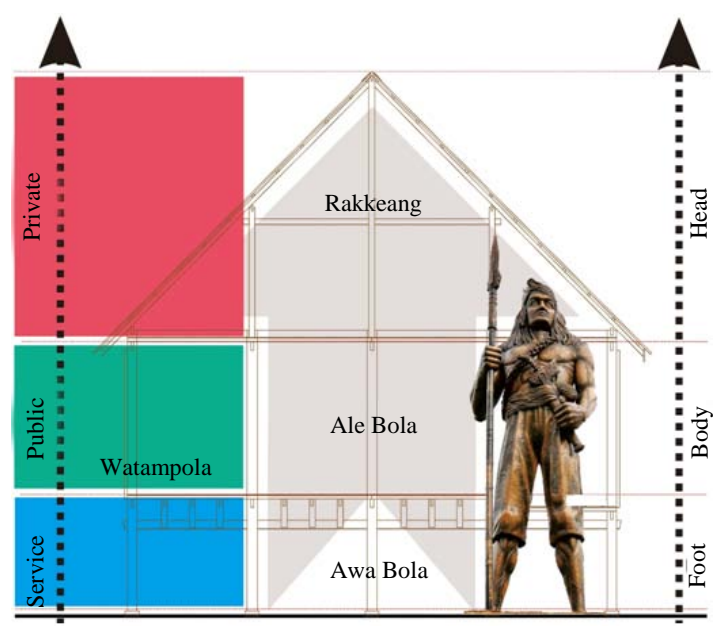

Fig. 3: Vertical space of Buginese aristocrat traditional house in Bone

Whereas horizontally, the type of space can be distinguished from the main room (indo bola) consisting of: lontang ri saliweng is located at the front functioning as a living room or space for ceremonial activities, lontang ri tenggah is located at the middle functioning as the main bedroom or private space, lontang ri laleng is located at the back as a bedroom for girls/elderly people who are elderly and tamping space as a symbol of nobility in the house which is generally, located on the side of the house body and the floor is rather low, functioning as a connector between the space, as well as a territorial sign of movement guests in the house, the pattern is not found in the concept of space in ordinary Buginese houses. This hierarchy is a space symbol of the nobility in the Buginese aristocrat house which distinguishes between two opposites such as high and low (Fig. 4).

While the supporting space consists of a terrace (lego-lego) and a kitchen (dapureng). The characteristics of each room are adjusted to the functions and activities 


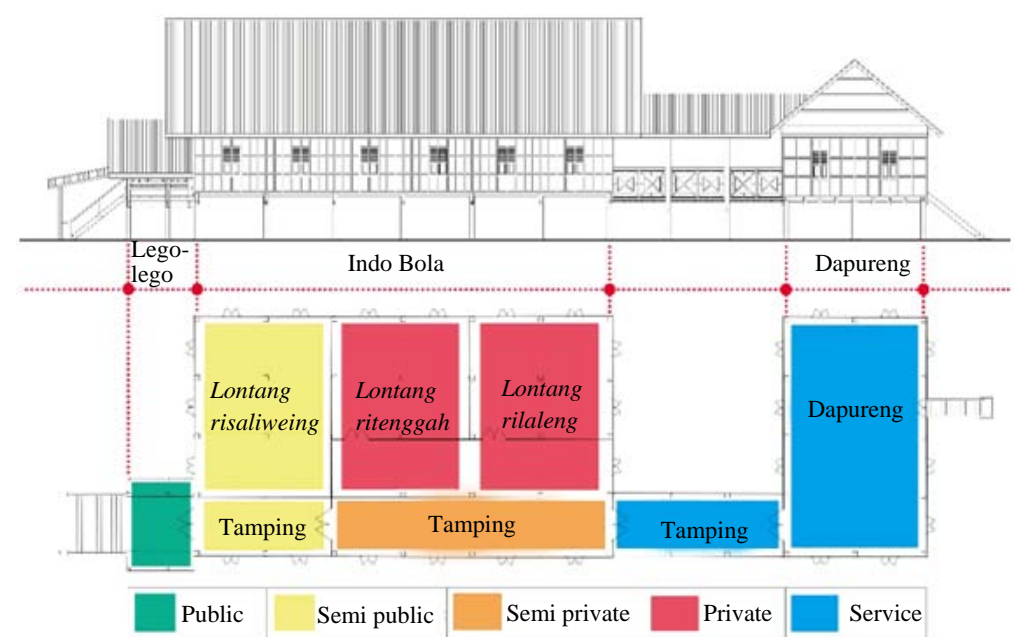

Fig. 4: Horizontal space of Buginese aristocrat traditional houses in Bone

as a means of fulfilling their daily lives which each room is influenced by an assessment of the meaning of the activities they do.

The layout of the outside house space is on a wide and symmetrical square of land while the pattern of the home space mass consists of the main room (Indo bola) supported by additional space with a strict separator forming an asymmetrical space mass, namely terrace and kitchen space. The house is generally, located on traditional land as a symbol of power in an area under its control.

\section{CONCLUSION}

The form concept of Buginese aristocrat traditional house architecture in Bone adheres to the principle of "Social Millieu" which the house serves as a static expression of aristocratic group role in presenting their stratification as an integrated form of unity with the aim to show their social status. The concept of space in Buginese aristocrat traditional house architecture in Bone adheres to the principle of "Cultural symbolization" which space serves as a symbol of microcosm which is believed by its predecessors, then recognized, linked and given symbolic meaning and then identified according to the community culture which describe the space specific characteristics such as space of sacred rakkeang, profane awa bola space, tamping as a connecting space as well as dividing the living room, private girls room (lontang ri laleng) and others. The space identity shows specific and unique conditions of each space as associated to physical characteristics, functions, relationships, location or position. The architectural concept of Buginese aristocrat traditional house in Bone is also influenced by social environment such as house layout in the customary environment which serves as a physical aspect that influences on the grouping of buildings based on their social background such as: kings, royal officials and royal descent. The grouping influences on the form and architectural space of the building in the area of settlement groups. While the process of acculturation of modern values with traditional values has gradually improved towards the improvement of its architecture.

\section{REFERENCES}

Akbar, A., A. Yudono, R. Wikantari and Mochsen, 2016. Characteristics territorial of tamping room of buginese aristocrats traditional houses in bone South Sulawesi. Proceedings of the International Seminar on Vernacular Settlements (ISVS-8), October 20th-22nd, 2016, GWA Campus-Hassaudin University, Makassar, Indonesia, pp: 227-239.

Koolhof, S., 1999. The La Galigo: A Bugis encyclopedia and its growth. J. Humanities Soc. Sci. Southeast Asia, 155: 362-387.

Oliver, P., 2003. Dwellings: The Vernacular House World Wide. Phaidon Press, Oxford, UK., ISBN: 9780714842028, Pages: 288.

Pelras, C., 2006. [Bugis Man]. Forum Jakarta-Paris, Jakarta, Indonesia, ISBN: 9789799939500, Pages: 449 (In Indonesian).

Rahman, N., 2012. Voices in Bugines Bone Locality. La Galigo Press, Makassar, Indonesia,.

Rapoport, A., 1969. House Form and Culture. Prentice Hall, Englewood Cliffs, USA., Pages: 162.

Yudono, A., 2008. Wisdom of traditional architecture stage house in modern residential. Hasanuddin University, Makassar, Indonesia, Makassar, Indonesia. 